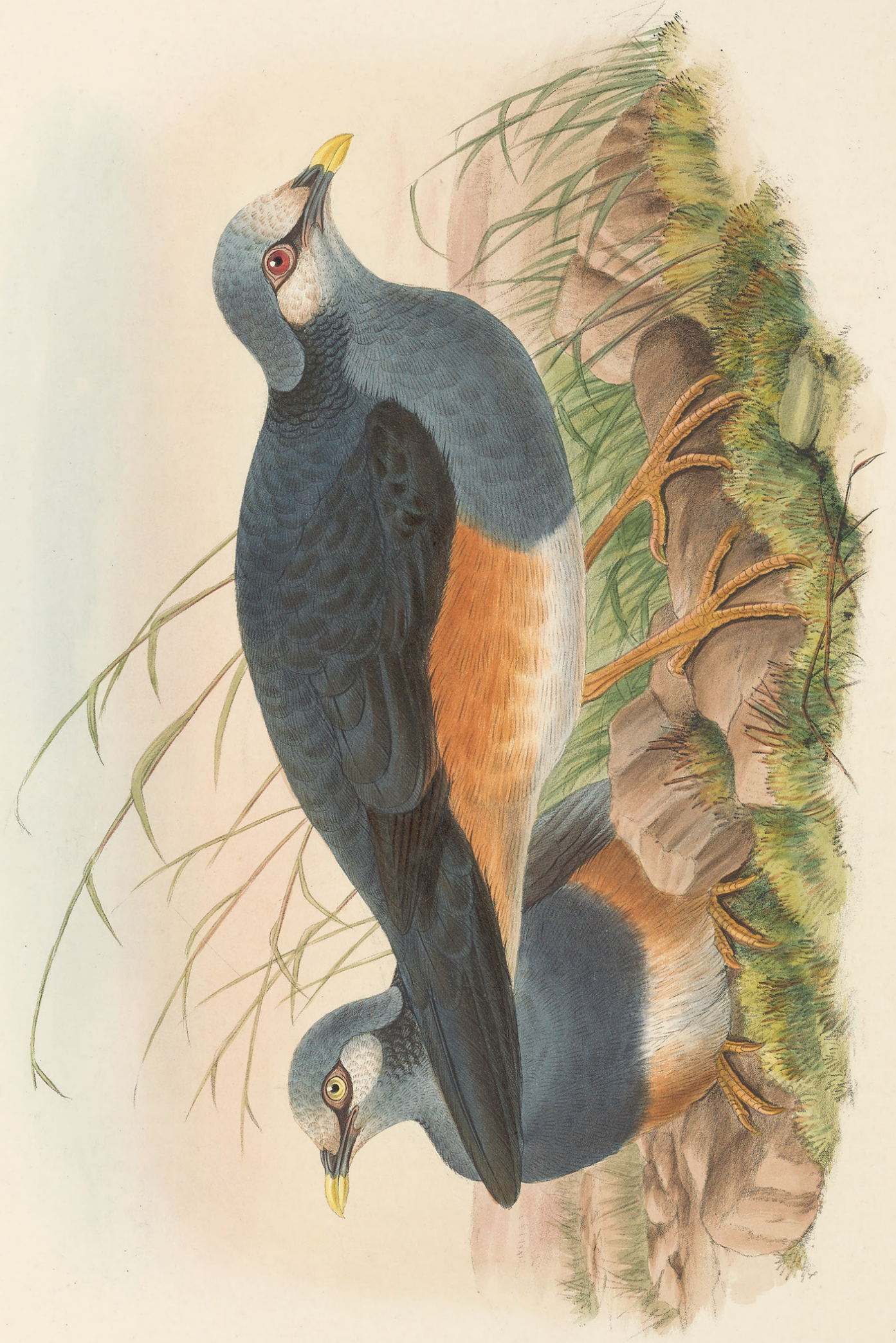




\title{
EUTRYGON TERRESTRIS.
}

\author{
Papuan Ground-Pigeon.
}

Trugon terrestre, Hombr. \& Jacq. Voy. Pôle Sud, Atlas, Oiseaux, pl. 28. fig. 1 (1846).

Trugon terrestris, Gray, Gen. B., App. p. 24 (1849).-Pucheran \& Jacq. Voy. Pôle Sud, Zool. iii. p. 123 (1853).Bp. Consp. ii. p. 86 (1854).-Id. Comptes Rend. xl. pp. 206, 221.-Gray, Proc. Z. S. 1858, p. 196.-Id. Cat. B. New Guinea, p. 48 (1859).-Id. Proc. Zool. Soc. 1861, p. 437.-Rosenb. Journ. für Orn.1861, p. 133.-Reichenb. Columbariæ, p. 45, sp. 97 (1862).-Finsch, Neu-Guinea, p. 179 (1865).-Wallace, Ibis, 1865, pp. 369, 392.-Id. Malay Archip. ii. p. 430 (1869).-Gray, Hand-l. B. ii. p. 245 (1870).

Trygon terrestris, Reichenb. Av. Syst. Nat. p. xxvi (1852).-Hartl. Journ. für Orn. 1854, p. 166.-Sundev. Meth. Nat. Av. Tent. p. 100 (1872).-Beccari, Ann. Mus. Civ. Genova, vii. p. 715 (1875).

Starnanas terrestris, Bp. Consp. ii. p. 86 (1854).

Eutrygon terrestris, Sclater, Proc. Linn. Soc. ii. p. 168 (1858).-Id. P. Z. S. 1873, p. 697.-Salvad. Ann. Mus. Civ. Gen. vii. p. 791 (1875); ix. p. 207 (1876); x. p. 161 (1877); D’Alb. \& Salvad. Ann. Mus. Civ. Gen. xiv. p. 124 (1879).-D’Alb. Nuova Guin. pp. 459, 528, 582, 588 (1880).—Salvad. Orn. Papuasia \&c. iii. p. 182.

Starnanas terrestris, Schleg. Mus. P.-B., Columbæ, p. 166 (1873).-Rosenb. Malay Archip. p. 396 (1879).

Phaps terrestris, Gieb. Thes. Orn. ii. p. 151 (1875).

THE above synonymy is taken from some sheets of the 'Ornitologia della Papuasia,' which my friend Count Salvadori was good enough to send me, on hearing that I was at work on the Pigeons of New Guinea; and I am much indebted to him for the assistance he has always given me in the production of the present work. His book contains a summary of all that is known of this Ground-Pigeon, which is really very little. It was discovered by the French voyagers Hombron and Jacquinot in Western New Guinea; Mr. Wallace also procured it on the western side of the island. In the Arfak Mountains the species was met with by Dr. Beccari and Signor D'Albertis, at Andai and Warbusi ; while Mr. Bruijn's hunters procured it at Dorey and also on the island of Salwatti. In the southern part of the island it was obtained by Signor D'Albertis on the Fly river; and we have seen several specimens from the interior of South-eastern New Guinea obtained by Mr. Goldie, in whose last collection from the back of the Astrolabe range were a good many individuals.

The original discoverers state that it is a Ground-Pigeon ; but they do not give any further particulars as to its habits.

The figures in the accompanying Plate have been drawn from specimens in my own collection, and will give some idea of this fine bird. I add a translation of the description given by Count Salvadori in the work above referred to.

Head, neck, upper part of back, and breast ashy grey, the sinciput and throat paler; forehead and chin dusky; cheeks greyish; sides of neck with an obsolete dusky spot on each ; middle of back, rump, upper tail-coverts, wing, and tail shining greyish olive ; middle of the abdomen pale isabelline, the sides and under tail-coverts rufescent; primary quills dusky, their outer margin, as well as that of the secondaries, rufescent towards the tip ; under wing-coverts dusky, partly isabelline; bill whitish, feet pale flesh-coloured; iris whitish ( $D^{\prime}$ Albertis) or red (Wallace). Signor D'Albertis also procured a bird on the Fly river which had the eye bright red.

The figures in the Plate are about the size of life.

[R. B. S.] 


\section{$2 \mathrm{BHL}$ Biodiversity Heritage Library}

Gould, John and Sharpe, Richard Bowdler. 1882. "Eutrygon terrestris, Papuan Ground-Pigeon [PI. 62]." The birds of New Guinea and the adjacent Papuan islands : including many new species recently discovered in Australia 5(XIII), -. https://doi.org/10.5962/p.322906.

View This Item Online: https://www.biodiversitylibrary.org/item/230441

DOI: https://doi.org/10.5962/p.322906

Permalink: https://www.biodiversitylibrary.org/partpdf/322906

\section{Holding Institution}

Smithsonian Libraries

\section{Sponsored by}

Biodiversity Heritage Library

\section{Copyright \& Reuse}

Copyright Status: Public domain. The BHL considers that this work is no longer under copyright protection.

This document was created from content at the Biodiversity Heritage Library, the world's largest open access digital library for biodiversity literature and archives. Visit BHL at https://www.biodiversitylibrary.org. 